\title{
Teatr jako metoda kształtowania kompetencji międzykulturowych
}

Streszczenie: Artykuł porusza kwestie rozwijania kompetencji międzykulturowych w procesie niezawodowej pracy teatralnej. Pierwsza część artykułu opisuje międzykulturowe poszukiwania twórców teatralnych XX wieku, które stanowią wprowadzenie do zagadnienia międzykulturowości w działaniach teatrów podejmujących w swej pracy temat wielokulturowego dziedzictwa północno-wschodniego pogranicza Polski. W drugiej części artykułu autorka analizuje praktykę teatralną jako metodę kształtowania kompetencji międzykulturowych aktorów, realizowaną poprzez formę artystycznej pracy nad dziedzictwem przeszłości.

Słowa kluczowe: teatr niezawodowy, teatr międzykulturowy, kompetencje międzykulturowe, dziedzictwo kulturowe

Doświadczanie własnej tożsamości kulturowej związane jest ze spotkaniem z Innym. Spotkanie z Innym jest skrzyżowaniem tego, co jest nam bliskie, z tym, co wychodzi „spoza nas”. Może być dobrodziejstwem, ale może też nieść ze sobą ryzyko konfliktu kulturowego. Kontakt z innością wymaga zdefiniowania siebie na nowo wobec drugiego człowieka, reprezentującego odrębny obraz świata, odmienny system wartości. Wiąże się to z budowaniem porozumienia, wymaga pewnych kompetencji wychodzenia naprzeciw, zwanych w literaturze przedmiotu kompetencjami międzykulturowymi. Kształtowaniu kompetencji międzykulturowych sprzyja forma działań, która prowadzi do odkrywania wartości w podstawowych sposobach porozumiewania się jednostek, w spotkaniu i dialogu (między osobami, pokoleniami, narodami, religiami). W artykule stawiam tezę, że teatr, który czerpie inspiracje z doświadczenia wielokulturowego dziedzictwa regionu, stanowi istotny edukacyjnie obszar kształtowania się kompetencji międzykulturowych. 


\section{Teatr międzykulturowy}

W sztuce to, co odmienne i nieznane, zawsze przyciągało artystów. Temat międzykulturowości jest szeroko rozpoznany w teatrze. Wśród wielu nazwisk możemy przywołać między innymi Antonina Artauda, który stanowił inspirację dla wielu twórców XX wieku. Artaud poszukiwał istoty teatru poprzez spotkanie z Innym. W trakcie licznych wędrówek teatralno-antropologicznych podążał w stronę rytuału oraz starodawnych widowisk o charakterze obrzędowym. Ich ślady dostrzegał m.in. w tańcach z Bali i wśród obrzędów ludu Tarahumara, zamieszkującego na terenie Meksyku. W doświadczeniu spotkania z nieznanym obrzędem chciał odnaleźć istotę przeżycia estetycznego. Dążył do spotkania Ja z Innym u źródeł teatru. Poszukiwał on „kultury prawdziwej", przechowującej formę pierwotnego teatru, by w indywidualnym, bezpośrednim spotkaniu z Dionizosem dotrzeć do istoty człowieczeństwa"1.

Kolejnym artystą, który przeniósł własne doświadczenia kontaktu z odmienną kulturą na deski teatru, był Jerzy Grotowski. Inscenizacja indyjskiego dramatu „Siakuntala” według Kalidasy jest jednym z rezultatów spotkania reżysera z kulturą Indii, Chin i Bliskiego Wschodu. Grotowski poszukiwał w kontaktach z Innym uniwersalnego dla naszej cywilizacji systemu znaków, którymi posługują się aktorzy w teatrze. Spotkanie z Innym skłoniło go do powrotu do własnych korzeni. „To, co robi aktor, winno pozostawać w związku z światem otaczającym, w łączności z kontekstem kulturalnym; z drugiej jednak strony, dla uniknięcia niebezpieczeństwa stereotypów, należy poszukiwać tego inaczej, wyzwalając niejako znaki z organicznego procesu ludzkiego organizmu” ". "Siakuntala” była ironiczną grą z widzem, obrazem teatru orientalnego opartego na stereotypowej wizji wynikającej z przekonań Europejczyków. Grotowski porzucił tę drogę, twierdząc, że: „poszukiwanie znaków w konsekwencji prowadziło do poszukiwania stereotypów"3, w wyniku czego rozpoczął zgłębianie rodzimych tradycji teatralnych, które doprowadziły go do teatru uczestnictwa.

1 A. Świątek: Między świętościa a szaleństwem. O podróży Antonina Artauda do Sierra Tarahumara, czyli do ziemi „zmartwychwstania” teatru. „Laboratorium Kultury" 2012, nr 1, s. 82-90.

2 J. Grotowski: Teksty z lat 1965-1969. Wrocław 1990, „Wiedza o kulturze”, s. 77.

3 Tamże, s. 77. 
Międzykulturowość w teatrze jest kojarzona również z nazwiskiem Eugenio Barby założyciela Nordisk Teaterlaboratorium/Odin Teatret oraz Międzynarodowej Szkoły Antropologii Teatru. W swojej wizji teatru euroazjatyckiego wskazuje na bliską edukacji międzykulturowej potrzebę dialogu. Dosłownie doprowadza do spotkania z Innym poprzez tworzenie międzynarodowych zespołów aktorskich, których głównym celem jest wymiana kulturowa pozwalająca na rozwój technik i doświadczeń teatralnych. Zdaniem Barby „dla lepszego określenia własnej tożsamości często konieczny jest przeciwny (a zarazem uzupełniający) punkt widzenia" ${ }^{4}$

Podobna idea towarzyszy poszukiwaniom teatralnym Petera Brooka, który wyreżyserował indyjski epos „Mahabharatę” przy współudziale wielonarodowego i wielowyznaniowego zespołu aktorów m.in. z Polski, Senegalu, Czadu, Indii, Hiszpanii, Libanu. Zabieg ten był dążeniem do uksztaltowania jednorodnej i spójnej wypowiedzi teatralnej opartej na odmienności kultur, wartości i doświadczeń aktorów oraz różnych tradycji teatralnych Wschodu i Zachodu ${ }^{5}$.

Opisane w ramach teatru międzykulturowego działania prowadziły w praktyce do wymiany kulturowej w pracy artystycznej. Reżyserzy z jednej strony poszukiwali uniwersalności teatru u jego źródeł, z drugiej strony elementów wspólnych dla praktyki teatralnej kultury Wschodu i Zachodu.

\section{Międzykulturowość w teatrze niezawodowym}

Opisany w pierwszej części artykułu zarys międzykulturowych poszukiwań wybitnych twórców teatralnych XX wieku chciałabym odnieść do międzykulturowych poszukiwań teatrów niezawodowych. Stosunkowo łatwo jest zdefiniować teatr w rozumieniu instytucjonalnym: jako rodzaj sztuki widowiskowej, czy też w pojęciu wykształconego w dziedzinie teatru profesjonalnego zespołu aktorów. Trudności pojawiają się podczas próby ujęcia w ramy teoretyczne teatru, który funkcjonuje niezależnie od formalnych zobowiązań, a w skład jego wchodzą często wyłącznie pasjonaci, amatorzy. W literaturze przedmiotu pojawiają się liczne próby tworzenia definicji te-

4. E. Barba: Teatr euroazjatycki, czyli szansa. „Dialog” 1993, t. 38, nr 8, s. 93.

5 G. Ziółkowski: Teatr Bezpośredni Petera Brooka. Gdańsk 2000, Wyd. słowo/ obraz/terytoria, s. 277-324. 
atru nieprofesjonalnego: teatr amatorski ${ }^{6}$, teatr szkolny ${ }^{7}$, teatr miłośników sceny ${ }^{8}$, teatr młodzieży ${ }^{9}$, teatr niezawodowy ${ }^{10}$. Egzemplifikacja ich bywa jednak często niejednoznaczna, obejmująca założenia tożsame dla różnych określeń, zależna od kontekstu prezentowania teatru. Analizując temat międzykulturowości w teatrze, chciałabym zwrócić uwagę na działania teatrów niezawodowych podejmujących w swej praktyce teatralnej temat dziedzictwa kulturowego miejsca, w którym istnieją ${ }^{11}$. Teatry niezawodowe, które stanowią przedmiot moich badań, to zespoły, które funkcjonują poza szkołą; w różnych grupach wiekowych: dzieci, młodzież, dorośli; dla których uczestnictwo w działaniach teatralnych jest zajęciem dodatkowym, realizowanym z powodów innych niż zarobkowe. Uczestnikami tych działań teatralnych są aktorzy niezawodowi; podejmujący w swej praktyce problematykę związaną z dziedzictwem kulturowym miejsca funkcjonowania teatru. Rozumiejąc podwójne znaczenie słowa „amator” (za słownikiem języka polskiego: osoba zajmująca się czymś nieprofesjonalnie, niemająca doświadczenia w danej dziedzinie lub miłośnik czegoś, osoba znajdująca w czymś przyjemność; człowiek zajmujący się czymś hobbistycznie ${ }^{12}$ ), świadomie zrezygnowałam z określenia teatru amatorskiego, aby uniknąć dwuznaczności pojęcia w toku postępowania badawczego. Założenia te potwierdziła debata z uczestnikami i widzami Ogólnopolskiego Festiwalu Teatrów Studenckich w 2013 w Warszawie, której celem było poszukiwanie dobrego określenia dla aktorów sceny niezawodowej wśród terminów: teatr studencki, teatr amatorski, teatr niezawodowy. Teatr amatorski został okre-

6 E. Orzechowski: Teatr amatorski. W: M. Fik (red.): Encyklopedia Kultury Polskiej XX wieku. Teatr. Widowisko. Warszawa 2000, Instytut Kultury.

7 M. Świeca: Rola teatru w autokreacji młodzieży. Kielce 2009, UHP.

8 W. Żardecki: Teatr $w$ refleksji i praktyce edukacyjnej. Ku pedagogice teatru. Lublin 2012, UMCS, s. 358.

9 J. Olszewska-Gniadek: Teatr młodzieży w świetle badań na terenie Krakowa. Kraków 2009, UJ.

10 W. Żardecki: Teatr $w$ refleksji i praktyce edukacyjnej. Ku pedagogice teatru. cyt. wyd., s. 358-359.

11 Artykuł ten prezentuje fragment koncepcji rozprawy doktorskiej pt. Transmisja dziedzictwa kulturowego w działaniach teatrów niezawodowych regionu Podlasia i Suwalszczyzny. Studium porównawcze z perspektywy edukacji regionalnej, przygotowanej pod kierunkiem naukowym prof. zw. dr. hab. Jerzego Nikitorowicza.

12 Stownik jezzka polskiego. www.sjp.pl (30.06.0216). 
ślony jako nacechowany pejoratywnie. Spośród wielu propozycji wybrano określenie: teatr niezawodowy ${ }^{13}$.

Termin teatr niezawodowy przyjmuję za Wiesławem Żardeckim, który definiuję go jako „alternatywny względem teatru instytucjonalnego, repertuarowego, model zespołu stowarzyszonych ludzi, zazwyczaj niewykształconych w akademiach teatralnych i nie mających odpowiedniego stażu, dla których właśnie aktywność teatralna jest zajęciem ubocznym, dodatkowym, realizowanym w czasie wolnym sposobem istnienia (a nie sposobem spędzania czasu wolnego), wynikającym jednak z głębokich motywacji emocjonalnych, z więzi z innymi członkami zespołu lub ze spełniania istotnych dla nich zadań społecznych, a przede wszystkim z wewnętrznej potrzeby wyrażania się (niezależnie czy jest to zwykła radość czy namysł nad sensem życia cierpienia i śmierci) poprzez tę właśnie sztukę"14.

Międzykulturowość, obecna w pracy teatrów niezawodowych, tworzy cenną przestrzeń do oddziaływań wychowawczych kształtujących kompetencje międzykulturowe. Tożsamość obszaru północno-wschodniego pogranicza Polski, będącego terenem moich badań, zbudowana jest na społeczno-kulturowej mozaice dziedzictwa historycznego. Badania pilotażowe prowadzone wśród teatrów niezawodowych, podejmujących w swej działalności problematykę dziedzictwa kulturowego, działających na Podlasiu i Sejneńszczyźnie, pozwoliły mi wyodrębnić dwa rodzaje teatrów: teatry monokulturowe (podejmujące problematykę i dziedzictwo określonej tradycji, np. Festiwal Teatrów Stodolanych - tradycja litewska) oraz teatry wielokulturowe (nawiązujące do wspólnotowego, wielokulturowego dziedzictwa miejsca, np. Kroniki Sejneńskie działające przy Ośrodku „Pogranicze - sztuk, kultur, narodów"). Wielokulturowe teatry niezawodowe korzystają z bogactwa różnorodności, jakie dostarcza im sytuacja wielowiekowego obcowania z Innym na pograniczu. W treści analizowanych przeze mnie spektakli, powstałych na terenach Podlasia i Sejneńszczyzny, zauważam inspiracje kulturą ukraińską, białoruską, litewską, rosyjską oraz katolicyzmem, prawosławiem, judaizmem. Wskazuje to na międzykulturowość doświadczeń w wymiarze „swojego teatralnego podwórka".

13 J. Niżnowski: Profesjonalni aktorzy sceny niezawodowej. http://www.nietak-t.pl/ index.php/numery/9-artykul/41-profesjonalni (30.06.2016).

14 W. Żardecki: Teatr $w$ refleksji i praktyce edukacyjnej. Ku pedagogice teatru. cyt. wyd., s. 358-359. 
Możemy zauważyć elementy wspólne dla pracy teatru międzykulturowego i działań wielokulturowych teatrów niezawodowych:

- międzynarodowy zespół aktorów i problematyka spektakli - teatry niezawodowe budują zróżnicowane pod względem etnicznym, narodowym, wyznaniowym zespoły aktorów, które przedstawiają wielowątkową, międzykulturową historię miejsca. Przykładem mogą tu być „Kroniki Sejneńskie” ${ }^{15}$, spektakl z udziałem dzieci z Sejn, Litwinów, Rosjan-staroobrzędowców i Polaków. Za scenariusz posłużyły opowieści i pieśni starszych ludzi, którzy noszą w sobie pamięć wielokulturowej historii miasteczka,

- poszanowanie odmienności -szacunek dla Innego jest obecny w przedstawianiu historii miejsca jako wspólnej, tworzonej przez wiele kultur opowieści o współistnieniu. Jest to ważne również z perspektywy młodych aktorów, którzy poznają własną tradycję a następnie wpisują ją w dziedzictwo miejsca obok opowieści sąsiadów, kolegów z teatru. Efekt ten wzmacniany jest poprzez obecność różnych języków pogranicza w narracji spektakli,

- wymiana kulturowa - na płaszczyźnie słowa, tradycji, rekwizytów. Niezawodowy teatr korzysta z bogactwa różnorodności, inspirując się wielokulturowością pogranicza (gwarą, lokalnymi obrzędami, pamiątkami),

- łączenie przeszłości z współczesnością - samo działanie teatralne upamiętniające historię miejsca jest pomostem pomiędzy tym, co było, a tym, co trwa. Największa praca dokonuje się jednak w indywidualnym doświadczeniu aktorów, w którym łączą oni dziedzictwo pogranicza kulturowego z dziedzictwem kultury europejskiej, wpisując swoją tożsamość w dialog pomiędzy i ponad kulturami.

Doświadczanie międzykulturowości w praktyce teatralnej jest wychowawczym działaniem w zakresie kształtowania kompetencji międzykulturowych. Pedagogiczny wymiar teatru niezawodowego, w myśl Żardeckiego, polega na przeniesieniu środka ciężkości z efektu końcowego pracy teatralnej, czyli premiery spektaklu, na proces twórczej aktywności procesu jego realizacji, opartego na osobistym zaangażowaniu i inicjatywie, który służy samowychowaniu i ubogacaniu uczestników, rozbudzaniu ich wyobraźni, wrażliwości; kształtowaniu samodzielności i odpowiedzialności. Zgodnie z autorem pojęcia wartość teatru niezawodowego „polega przede wszystkim na licznych sytuacjach wychowawczych z niego wynikających, na poszukiwaniu wspól-

15 Strona projektu: https://kronikisejnenskie.wordpress.com/ (6.07.2016). 
nej płaszczyzny rozwiązywania nurtujących go problemów przedstawianych z perspektywy uczestnika, na wypowiadaniu się w ważnych dla niego sprawach za pomocą języka, którym on włada"16.

\section{Kompetencje międzykulturowe w pracy teatrów niezawodowych}

Faktem jest, że żyjemy w przestrzeni niejednorodnej, w której nakładają się na siebie różne wzory zachowań, odmienne wartości czy tradycje kulturowe. Naturalnym efektem takiego nałożenia staje się wzrost interakcji kulturowych, przenikania, wzajemnych oddziaływań, ale także konfliktów i napięć. Przyczyny takiego stanu rzeczy związane są ze wzrastającą mobilnością kultur oraz rozwojem technologicznym, który powoduje, że przestrzeń staje się coraz bardziej bezgraniczna i wychodzi poza sferę terytorium oraz realnego obcowania, wkraczając również na obszar wirtualnej rzeczywistości. Skraca to dystans, ale powoduje również technologiczne oblężenie tożsamości kulturowej, która wśród wielości informacji musi odnaleźć punkt odniesienia do definiowania swojego bycia w świecie. Ze względu na nasilenie kontaktów międzykulturowych na różnych płaszczyznach powstaje konieczność kształtowania kompetencji do spotkania i dialogu ${ }^{17}$. Kontakt $\mathrm{z}$ odmiennością stał się elementem naszej codzienności. Proces poznawania Innego jest jednak nadal trudny. Jak wskazuje Hanna Mamzer, ,jest tym trudniejszy, że wymaga poznania przede wszystkim samego siebie i przynajmniej uświadomienia sobie swoich własnych ograniczeń. Dotyczy to zarówno sposobu autopercepcji podmiotów indywidualnych jak i zbiorowości"18. W dobie rozwoju cywilizacji technicznej bardzo istotna z pedagogicznego punktu widzenia jest możliwość pracy edukacyjnej na rzecz dialogu międzykulturowego w rzeczywistym bezpośrednim kontakcie, który jest możliwy w praktyce teatralnej.

Praca nad spotkaniem z Innym rozpoczyna się od refleksji nad własną tożsamością kulturową i kształtowaniem kompetencji kulturowych. Mirosław Sobecki ukazuje je w dwóch ujęciach: szerokim, które jest procesem przysto-

16 W. Żardecki: Teatr $w$ refleksji i praktyce edukacyjnej. Ku pedagogice teatru. cyt. wyd., s. 359.

17 S. Jaskuła, L. Korporowicz: Międzykulturowa kompetencja komunikacyjna jako transgresja, a komunikacyjna jako transgresja. „Pogranicze. Studia Społeczne” 2013, t. XXI, s. 122-127.

18 H. Mamzer: Jak reprezentować odmienność kulturową? W: J. Isański (red.): Komunikowanie międzykulturowe - szanse i wyzwania. Poznań 2009, UAM, s. 161. 
sowania jednostki do funkcjonowania w grupie społecznej, zapewniającym jej elementarną spójność, oraz węższym, które związane jest z wyposażeniem jej w „spójny zespół symboli i kodów znaczeniowych, który pozwoli na swobodne poruszanie się i twórcze włączenie w kulturę duchową grupy"19. Kompetencje kulturowe pozwalają swobodnie poruszać się w obszarze dorobku kulturowego własnej grupy, co stanowi ważny krok w kierunku otwartej interakcji z przedstawicielami innych kultur.

Kompetencje międzykulturowe, przygotowujące jednostkę do procesu interakcji z Innymi, są pojęciem trudnym do jednoznacznego zdefiniowania, co wynika z wielości ujęć i stanowisk wykraczających poza obszar zainteresowań jednej tylko nauki czy dyscypliny. Sławomir J. Magala, pisząc o kompetencjach międzykulturowych, używał metafory plecaka lub zestawu narzędzi, „który samodzielnie kompletują wszyscy uczący się ludzie, jeśli w jednym miejscu muszą radzić sobie z różnymi oprogramowaniami kulturowymi (...) uczą się ponieważ muszą poruszać się pośród rożnych kultur i subkultur"20.

Na potrzeby podjętych w tym artykule analiz chciałabym zwrócić uwagę na sposób myślenia o kompetencjach międzykulturowych Jonasa Stiera ${ }^{21}$. Zgodnie z jego sposobem definiowania, pojęcia kompetencje międzykulturowe składają się z kompetencji dotyczących treści (content-competencies, know that-aspects) i kompetencji procesualnych (processual competencies, know how-aspect), które dzieli on na intra- i interpersonalne. Kompetencje dotyczące treści zawierają takie elementy, jak: fakty historyczne, język, kody niewerbalne, wzory zachowań, tradycja, role społeczne, wartości, normy, zwyczaje, tabu, symbole. Kompetencje procesualne intrapersonalne to: decentracja, alternacja perspektywy, wchodzenie w role społeczne, rozwiązywanie problemów, otwartość i refleksyjność. Interpersonalne natomiast to: wykrywanie i interpretowanie odmienności w zachowaniach niewerbalnych, rozpoznawanie emocjonalnego kontekstu komunikacji, opanowanie kodów werbalnych i niewerbalnych, świadomość stylów interakcji, wrażliwość sytuacyjna na przekaz ${ }^{22}$.

19 M. Sobecki: Kultura symboliczna a tożsamość. Białystok 2009, Wydawnictwo Uniwersyteckie „Trans Humana”, s. 97.

20 S. J. Magala: Kompetencje międzykulturowe. Warszawa 2011, JAK, s. 40.

21 J. Stier: Internationalisation, intercultural communicationa and intercultural competence. „Journal of Intercultural Communication” 2006, nr 11, s. 6-7.

22 Za: K. Gajek: Kompetencje międzykulturowe jako element kultury wspótczesnej organizacji - dylematy teorii i praktyki. „Problemy Zarządzania” 2011, vol. 9, nr 2 (32), s. 208. 
W kolejnej części artykułu postaram się przełożyć elementy tak rozumianych kompetencji międzykulturowych na pracę teatrów niezawodowych zajmujących się problematyką dziedzictwa kulturowego miejsca. Wymienione w pierwszej kolejności kompetencje dotyczące treści wpisują się w proces przygotowywania spektaklu. W analizowanych przeze mnie grupach teatralnych często praca nad spektaklem rozpoczynała się od historycznego ustalenia i rozpoznania znaczących dla społeczności wydarzeń. Wielokulturowy charakter miejsc powodował, że ich historia zapisana była często w różnych językach (co wymagało nauki słów, współpracy np. Polaków i Litwinów we wzajemnym tłumaczeniu tekstów). Bohaterami scenariusza zostawały często postacie historyczne osadzone w przeszłości miejsca, przedstawiciele różnych grup etnicznych, narodowych, wyznaniowych, które poprzez swoją historię wnosiły w spektakl odmienne tradycje, wzory zachowań, znaczące symbole. Praca nad wielokulturowym materiałem polegała zatem na wspólnym odkodowywaniu znaczeń. Praca ta była szczególnie ważna, gdyż urealniała wspólnotowość miejsca i historii, wymagała współdziałania we wzajemnym tłumaczeniu znaków i symboli, budując tym samym wiedzę na temat odmiennej kultury poprzez rzeczywiste, twórcze, koleżeńskie zadanie.

Drugi wymieniony przez Stiera element kompetencji międzykulturowych związany jest z procesem. W odniesieniu do teatru - procesem jest praca nad spektaklem. Praca nad kompetencjami procesualnymi intrapersonalnymi jest wpisana w praktykę teatralną. Jest zwróceniem się ku doświadczeniom odmiennym - teatr to nie tylko kreacja aktorska, ale również pogłębiona refleksja. Empatyczne wychodzenie naprzeciw Innego, behawioralne doświadczanie inności poprzez odgrywane role, dyskusje nad sensem przekazu, wspólne rozwiązywanie problemów i otwartość na odmienną interpretacje to elementy, które stanowią treść pracy nad spektaklem. W odniesieniu do wielokulturowej problematyki teatr umożliwia doświadczanie i naukę Inności w wymiarze pracy artystycznej. Teatr uruchamia wiele wrażeń, emocji, przeżyć, doznań doświadczanych w stosunku do siebie samego, jak i w konfrontacji z innym, wespół z innym. Angażuje we wspólny proces tworzenia i aktywności. Kompetencje procesualne interpersonalne w teatrze to kolejny krok do poznania Innego poprzez włączenie osobistego, emocjonalnego kontekstu do przygotowań teatralnych. To indywidualny wymiar budowania świadomości roli, którą gramy. Poprzez opanowanie techniki i kodów praca ta prowadzi do budowania indywidualnej relacji z postacią, oferującej możliwość artystycznej improwizacji gestów i zachowań w odgrywanej roli. Proces przygotowywania spektaklu wychodzi poza sferę artystyczną i staje się bliski uczestnikom. 


\section{Teatr jako metoda kształtowania kompetencji międzykulturowych}

Powyższe analizy ukazują teatr, który czerpie inspirację z doświadczenia wielokulturowego dziedzictwa regionu jako metodę kształtowania kompetencji międzykulturowych. Praktyka teatralna daje aktorom możliwość wymiany wiedzy i doświadczeń, wzajemnego tłumaczenia sobie swoich kulturowych wartości, swojej wizji świata w służbie wyższego artystycznego celu, który jest budowany ponad różnicami. Teatr stwarza przestrzeń do komunikacji i otwiera na odmienny punkt widzenia. Kształtuje to postawę tolerancyjną i otwartość na świat. Nabywanie kompetencji dialogu w procesie teatralnym jest wpisane w akt twórczy, pozwala w pełni zrozumieć treść spektaklu. Teatr buduje relacje pomiędzy uczestnikami, których podstawą są silne emocje towarzyszące współpracy w realizacji przedstawienia. Każda praktyka teatralna nastawiona jest na człowieka, na to aby działał on z drugim człowiekiem, dzięki czemu pobudza się chęć wspólnego widzenia świata i wspólnego w nim uczestnictwa.

\section{Bibliografia}

Barba E.: Teatr euroazjatycki, czyli szansa. „Dialog” 1993, tom 38, nr 8. Gajek K.: Kompetencje międzykulturowe jako element kultury współczesnej organizacji - dylematy teorii i praktyki. „Problemy Zarządzania” 2011, vol. 9, nr 2 (32).

Grotowski J.: Teksty z lat 1965-1969. Wrocław 1990, „Wiedza o kulturze”. Jaskuła S., Korporowicz L.: Międzykulturowa kompetencja komunikacyjna jako transgresja, a komunikacyjna jako transgresja. „Pogranicze. Studia Społeczne" 2013, t. XXI.

Magala J. S.: Kompetencje międzykulturowe. Warszawa 2011, JAK.

Mamzer H.: Jak reprezentować odmienność kulturowa?. W: J. Isański (red.):

Komunikowanie międzykulturowe - szanse i wyzwania. Poznań 2009, UAM.

Niżnowski J.: Profesjonalni aktorzy sceny niezawodowej. http://www.nietak-t. $\mathrm{pl} /$ index.php/numery/9-artykul/41-profesjonalni (30.06.0216).

Olszewska-Gniadek J.: Teatr młodzieży w świetle badań na terenie Krakowa. Kraków 2009, UJ. 
Orzechowski E.: Teatr amatorski. W: M. Fik (red.): Encyklopedia Kultury Polskiej XX wieku. Teatr. Widowisko. Warszawa 2000, Instytut Kultury.

Słownik Języka Polskiego. www.sjp.pl. (30.06.0216).

Sobecki M.: Kultura symboliczna a tożsamość. Białystok 2009, Wydawnictwo Uniwersyteckie „Trans Humana”.

Stier J.: Internationalisation, intercultural communicationa and intercultural competence. „Journal of Intercultural Communication” 2006, vol. 11.

Świątek A.: Między świętościq a szaleństwem. O podróży Antonina Artauda do Sierra Tarahumara, czyli do ziemi „zmartwychwstania” teatru. „Laboratorium Kultury" 2012, nr 1.

Świeca M.: Rola teatru w autokreacji młodzieży. Kielce 2009, UHP.

Ziółkowski G.: Teatr Bezpośredni Petera Brooka. Gdańsk 2000, Wydawnictwo słowo/obraz/terytoria.

Żardecki W.: Teatr $w$ refleksji i praktyce edukacyjnej. Ku pedagogice teatru. Lublin 2012, UMCS.

\section{Theatre as a method of shaping intercultural competences}

Abstract: The author discusses the question of developing intercultural competence through amateur theatre work. The first part of the article describes intercultural explorations of theatre artists of the twentieth century, which serve as an introduction to the issue of interculturalism in the activities of amateur theaters which focused in his work on multicultural heritage of the North-Eastern Polish borderland. In the second part of the article, the author analyses the theatre as a method of forming intercultural competence of actors realized through a form of creative work on the heritage of the past.

Key words: amateur theatre, intercultural theatre, intercultural competence, cultural heritage 